\title{
Australian legal dynasties: The Stephens and the Streets
}

KAREN FOX

The word 'dynasty' evokes images of hereditary rulers, striding dusty castle corridors where their families have ruled for centuries. It might also suggest dominant political families, like the Kennedys, in republican settings like the United States of America. The term can, however, also be used to describe prominent families in other fields, such as business or the law, in which a succession of individuals from one family have scaled the heights of their profession. A number of such families have lived and worked in Australia, and their stories are captured in the biographies told in the Australian Dictionary of Biography and the associated People Australia websites. This article explores the stories of two families who might be thought of as Australian legal dynasties: the Stephens and the Streets. Between them, these two families produced across several generations four chief justices of New South Wales - and one person who turned the job down-as well as at least four other judges, and numerous successful barristers and solicitors.

The Stephens family who came to be renowned in the legal world in Australia were a branch of a notable British clan, several of whose members were distinguished in the law in England, and one of whom-Sir Leslie Stephen-was the first editor of the Oxford Dictionary of National Biography. The first lawyer in the branch of the family that was to become eminent in Australia seems to have been James, a conveyancer, who was born in $1733 .{ }^{1}$ James and his wife Sibella had several children. Among them was another James, who became a member of parliament and Master in Chancery, and whose own children included Sir George Stephen QC; Henry Stephen, serjeantat-law; and Sir James Stephen, permanent under-secretary of state for the colonies. ${ }^{2}$ Another son of James and Sibella was John. Initially a lawyer with a large practice in England, he moved to the West Indies with his wife, Mary Pasmore, who was herself the daughter of a solicitor. There, at St Kitts in 1802, was born Alfred. ${ }^{3}$

\footnotetext{
1 J. M. Bennett, Sir Alfred Stephen: Third Chief Justice of New South Wales 1844-1873 (Sydney: The Federation Press, 2009), 2.

2 Bennett, Sir Alfred Stephen, 2; Ruth Bedford, Think of Stephen: A Family Chronicle (Sydney: Angus and Robertson, 1954), 2.

3 Bennett, Sir Alfred Stephen, 2-3; Bedford, Think of Stephen, 4.
} 
It was from Alfred and his father that the Australian legal dynasty of Stephens would develop. After a childhood spent largely in England, Alfred returned to St Kitts with his father following a financial failure, and there worked in John's office, learning the law. ${ }^{4}$ Returning to England in 1818, Alfred became a student at Lincoln's Inn, living at first with his mother. He read law with his cousin Henry, and also benefited from an association with James, the cousin who later became under-secretary at the Colonial Office. ${ }^{5}$ In 1824, John was appointed as commissioner of the Courts of Requests in New South Wales, and Alfred decided that he too would seek better prospects in Australia. ${ }^{6}$ With his wife Virginia (née Consett), he arrived in Hobart in January $1825 .^{7}$

Admitted to the Bar in Van Diemen's Land in February 1825, before long Alfred had become solicitor-general and crown solicitor; he later became attorney-general. ${ }^{8}$ According to his biographer, John Bennett, he made a significant contribution to legal reform during his time in Van Diemen's Land, particularly by playing a part in the institution of a civil jury of four people. ${ }^{9}$ After Virginia died in 1837, however, he resigned his post as attorney-general. The following year he married Eleanor Bedford. Meanwhile, John had become the first puisne judge of the New South Wales Supreme Court, and twice acted as chief justice in the absence of Sir Francis Forbes.

Alfred's next move was to New South Wales, where, like his father, he soon became a puisne judge. Sir James Dowling, who was then chief justice, was pleased at the appointment. His wife, Lady Dowling, reported to her son:

The accession of another judge is material to your father especially as $\mathrm{Mr}$ Stephen is clever, gentlemanly and cordial, with the advantage of 13 years colonial experience, above all price in such a position. ${ }^{10}$

A few years later, in 1844, Alfred became acting chief justice; he was confirmed in the office in June 1845. In Bennett's view, it was:

A distinguished tenure, not only because of his practical, if sometimes severe, decisions and his keen legal mind, but also because of his untiring efforts to dispense justice efficiently and to improve its administration. ${ }^{11}$

\footnotetext{
Bennett, Sir Alfred Stephen, 3-5; Bedford, Think of Stephen, 4-5.

Bennett, Sir Alfred Stephen, 7-10; Bedford, Think of Stephen, 5-6.

'Government and General Orders', Sydney Gazette and New South Wales Advertiser, 12 August 1824, 1.

Bennett, Sir Alfred Stephen, 10-11; Bedford, Think of Stephen, 9-10.

J. M. Bennett, Portraits of the Chief Justices of New South Wales 1824-1977 (Sydney: John Ferguson, 1977), 20.

Bennett, Portraits of the Chief Justices, 20.

10 Bennett, Sir Alfred Stephen, 111.

11 Bennett, Portraits of the Chief Justices, 20-21.
} 
He worked hard, as a letter from Eleanor to his daughter Virginia Hewlett in England in 1856 lamented:

Your suspicions are right as to your Papa having too much to do. He really looks much worn and fatigued and suffers very frequently from headaches. He literally never seems to have a leisure hour. ${ }^{12}$

Briefly the first president of the Legislative Council after responsible government, following his retirement from the chief justiceship in 1873 Sir Alfred was a member of the council and lieutenant-governor (1875-91). He died in October 1894. In a tribute to him, Sir William Windeyer praised 'the swiftness of his apprehension [and] the subtleness of his reasoning and his grasp of principle', and recalled his enjoyment of his friendship. ${ }^{13}$

Sir Alfred was the most successful and well-known of John Stephen's sons, but he was not the only one to enter the legal profession, nor to achieve high position. At the time of John's death, in 1833, all of Alfred's four surviving brothers were also 'practising Law in some form or other in various colonies'..$^{14}$ His eldest brother, Sidney, was a barrister in St Kitts and Australia before moving to New Zealand as a puisne judge of the Supreme Court. ${ }^{15}$ John was a Police Court practitioner and an alderman for the city of Melbourne. ${ }^{16}$ Younger than Alfred were Francis and George. Francis was a solicitor in Sydney and proprietor of the Australian newspaper. ${ }^{17}$ George, who had been a clerk in the Supreme Court of Van Diemen's Land during his brother's time as solicitor-general, and who had briefly worked with Francis in his legal office in Sydney in 1836, became advocate-general and crown solicitor in South Australia in 1838 as a result of a lucky confusion of himself with Alfred. After a stint as colonial secretary in the colony, and another as government secretary to Sir John Hindmarsh in England, he returned to Australia, where he practised law, entered politics and conducted business. He ended his career a faith healer, in which occupation he became something of a celebrity. In 1881, the Goulburn Herald described how he had attended to one man by:

Breathing on the parts affected, making passes, and then ordering the patient to throw away his stick, which he did, and walked around the room and downstairs with the utmost celerity. ${ }^{18}$

12 Bedford, Think of Stephen, 120.

13 'Sir Alfred Stephen. Judge Windeyer's Tribute. Remarks by Attorney-General', Evening News (Sydney), 18 October 1894, 6.

14 Bedford, Think of Stephen, 19.

15 Ronald Jones, 'Stephen, Sidney', An Encyclopaedia of New Zealand, ed. A. H. McLintock, originally published 1966, Te Ara - the Encyclopedia of New Zealand, updated 22 April 2009, accessed 12 June 2014, www. TeAra.govt. nz/en/1966/stephen-sidney.

16 'Funeral of the Late John Stephen, Esq'., Courier (Hobart), 4 November 1854, 2.

17 'Anecdotal Photographs. No. 51.-Sir Alfred Stephen, C.B., G.C.M.G', Table Talk (Melbourne), 21 October $1892,3$.

18 'Mr. George Milner Stephen', Goulburn Herald, 30 July 1881, 2. 
Sir Alfred Stephen had 18 children, nine with Virginia and nine with Eleanor, although three did not survive past their first year. Of his eight surviving sons, five entered the legal profession. Eleanor observed that 'the Law seems the easiest and most natural of the professions for our boys', for 'Papa's position gives him the opportunity of putting his sons forward in the Law, whereas other professions require what he has not-money ${ }^{19}{ }^{19}$ Consett, Alfred's second son, was admitted as a barrister and solicitor in Van Diemen's Land in 1849, and later that year also in New South Wales. ${ }^{20}$ After a short time in practice with Charles Lowe, from 1852 until 1864 he practised alone. His brother Septimus, who had been articled to Consett since 1858, became his partner in the firm of Stephen and Stephen in $1864 .{ }^{21}$ Septimus continued the practice after his brother's death in 1872, and it eventually became known as Stephen, Jaques and Stephen. The two brothers also shared a parliamentary career; Consett was the member for Canterbury in the Legislative Assembly in New South Wales for almost a year, from December 1869 to December 1870, and Septimus held the same seat between 1882 and 1887, when he moved to the Legislative Council.

Sir Alfred's third son, (Sir) Henry, was an associate to Sir James Dowling as well as to his father, and was admitted to the Bar in 1850 . He had a general practice, and, in 1879, was appointed QC. Having several times refused the position of solicitor-general, in 1879 he also refused that of Supreme Court judge on the grounds that the salary would be insufficient, being much less than he could make as a barrister. Some years later, however, in 1887, he accepted the job, becoming a puisne judge of the New South Wales Supreme Court. ${ }^{22}$ Later, he was acting chief justice (1902-04). In 1914 he recalled that he first went on circuit 'in the bushranging days'. 'I remember procuring a revolver', he said, 'though I had a feeling I would be shaking too much to do any good with it if the ruffians bailed me up. ${ }^{23}$

Two other sons also made their living in the legal profession. Cecil, who was Sir Alfred's sixth son, was an associate to his father before entering practice himself. Appointed KC, he was also offered a position on the Supreme Court bench, and even the role of chief justice, though he never accepted either. According to an obituary, he was 'noted for his great ability as a pleader', and had 'that calm, dispassionate judgment and impartial view that, combined with the highest legal talent and

19 Bedford, Think of Stephen, 133, quoted in Martha Rutledge, 'Stephen, Sir Alfred (1802-1894)', Australian Dictionary of Biography, National Centre of Biography, The Australian National University, adb.anu.edu.au/ biography/stephen-sir-alfred-1291/text7645, published first in hardcopy 1976, accessed online 22 May 2014.

20 'Local', Cornwall Chronicle (Launceston), 14 July 1849, 718; 'Law Intelligence', Sydney Morning Herald,

24 December 1849, 2.

21 See Sydney Morning Herald, 2 September 1864, 1.

22 'Mr. Justice Stephen', Sydney Morning Herald, 21 May 1887, 13.

23 'Sir Henry Stephen. Eighty-Eighth Birthday. Talk About Old Times', Sydney Morning Herald, 7 December 1916, 6 . 
ability, would have made him an ideal Judge'. ${ }^{24}$ Ernest, the youngest surviving son, was admitted as a solicitor in 1871 . Briefly in the family firm, he was later a senior partner in another. ${ }^{25}$ According to Sir Alfred's granddaughter Ruth Bedford, 'some said he was the most brilliant of the brothers, but he had too little staying power and too many hobbies'. He played the piano so well that 'one wished he would never get off the piano stool'. ${ }^{26}$

Both grandsons and great-grandsons followed the family tradition and entered the law. Among Sir Alfred's grandsons, (Alfred) Consett was admitted as a solicitor in 1882 and became a partner in Stephen, Jaques and Stephen, as did (Sir) Colin, who was admitted to practice and made a partner of the firm in 1896, and Leonard, who was known for his philanthropy, especially with the Boys' Brigade. ${ }^{27}$ Colin was also a noted amateur jockey, whose first win was in 1892 on a horse named Pro-Consul; later in life he chaired the Australian Jockey Club. ${ }^{28}$ Henry Montagu practised as a barrister in Sydney, while Noel Campbell was admitted as a solicitor in England, although he never practised. Milner was admitted to the Bar in 1896, and went into practice on his own. He became a KC in July 1928. Appointed a puisne judge in 1929, he became 'the fourth generation of his family to sit on the Supreme Court bench in New South Wales' ${ }^{29}$ Alfred Hewlett, a son of Sir Alfred's daughter Virginia, who had moved to England on her marriage, came out to Australia to be articled to Septimus, but later decided against entering the law and returned to England, where he took orders. ${ }^{30}$ Another grandson, Alfred John, was intending to study for the Bar when he died of typhoid fever on a trip to India in 1890.

Among Sir Alfred's great-grandsons were both eminent lawyers and some who may have been, had not their lives been cut short. Adrian Consett, who had received an LLB degree in 1915 and who was also a noted writer of plays and essays, was killed in action in March 1918; he had been awarded the Croix de Guerre for his actions at the Somme and the Military Cross for his conduct at Passchendaele. Montagu Consett died at the age of 32 in 1920, a 'promising' young member of Stephen, Jaques and Stephen who had been admitted as a solicitor in 1914. (Sir) Alastair began his legal career in 1923 as an articled clerk in Stephen, Jaques and Stephen, being admitted as a solicitor and becoming a partner in the firm in 1926, where

\footnotetext{
24 'Death of Mr. C. B. Stephen, K.C. A Distinguished Career', Sydney Morning Herald, 4 July 1910, 8.

25 Bedford, Think of Stephen, 176.

26 Bedford, Think of Stephen, 176.

27 'Late Mr. Leonard Stephen. Proposed Memorial', Sydney Morning Herald, 13 December 1923, 9; 'Boys' Brigade. Leonard Stephen Memorial. Proposed Gymnasium', Sydney Morning Herald, 11 January 1924, 8.

28 'A.J.C. Chairman. Death of Sir Colin Stephen. Notable Figure. Formerly an Amateur Rider', Sydney Morning Herald, 15 September 1937, 18; 'Sydney Turf Club. Queen's Birthday Meeting. Second Day, Saturday, May 28', Sydney Morning Herald, 30 May 1892, 6.

29 Martha Rutledge, 'Stephen, Edward Milner (1870-1939)', Australian Dictionary of Biography, National Centre of Biography, The Australian National University, adb.anu.edu.au/biography/stephen-edward-milner-1300/ text15101, published first in hardcopy 1990, accessed online 22 May 2014.
}

30 Bedford, Think of Stephen, 229-30, 242. 
he remained until his retirement in 1975. Leslie Consett was admitted to the Bar in November 1927, his admission being reported by the Sydney Morning Herald, which emphasised that he and Alastair 'represent[ed] the fifth generation' of the family involved in the law and judiciary in Sydney. ${ }^{31} \mathrm{He}$, too, became a member of Stephen, Jaques and Stephen.

Lawyers and judges were also to be found in the wider Stephen family. Sir Alfred's nephew Frank, who had, like him, been born at St Kitts, was solicitor to the Melbourne City Council. Both of Frank's sons, Frank junior and Sidney, became solicitors in Melbourne. Alfred's first cousin once removed, James Wilberforce Stephen, was a judge of the Victorian Supreme Court from 1874.

Reading law with Cecil Bedford Stephen in the 1880s was a young Philip Whistler Street, the founder of another great New South Wales legal dynasty. Born in 1863, he was a great-grandson of William Lawson, one of the early explorers of the Blue Mountains. He also had at least one eminent lawyer and judge in his ancestry: Sir Thomas Street (1625-95), a judge of the Court of Common Pleas from 1684. ${ }^{32}$ With his brothers John William and Edric, Philip attended school at Miss Amelia Hall's private school at Waverley House, where Alfred Consett Stephen was also a pupil. ${ }^{33}$ After admission as a solicitor in 1885, John practised in partnership with Banjo Paterson for some years, and then in sole practice. Another of Philip's brothers, Kenneth Leslie, began in the legal profession, being articled to Alfred Jaques of Stephen, Jaques and Stephen. Following his father's death, however, he gave up his articles and went to work on pastoral stations, later moving to the United States. ${ }^{34}$

John Rendell Street, Philip's father, greatly admired the legal profession, and Supreme Court judges like Sir William Windeyer, Sir William Manning and Sir George Long Innes (who had been an associate of Sir Alfred Stephen). Influenced by his father's feelings — as perhaps his brothers were-Philip entered the law. ${ }^{35}$ He was admitted to the Bar in 1886, a year after his brother John's admission to practice as a solicitor; his admission was moved by Cecil Stephen. ${ }^{36}$ In 1888 he married Belinda Poolman, who was later described by her son Kenneth as 'an indefatigable worker in all the great philanthropic and humanitarian movements in New South Wales' ${ }^{37}$ Having built up a good practice, Philip was appointed an acting judge of the New South Wales Supreme Court in July 1906, becoming in February the following year judge

31 'Legal Family. Five Generations. Interesting Record', Sydney Morning Herald, 19 November 1927, 17.

32 Bennett, Portraits of the Chief Justices, 47; Kenneth Whistler Street, Annals of the Street Family of Birtley

([Sydney: K. W. Street], 1941), 9.

33 Street, Annals, 127.

34 Street, Annals, 135-36.

35 Street, Annals, 139.

36 'Law Report', Sydney Morning Herald, 26 August 1886, 5.

37 Street, Annals, 153. 
in bankruptcy and probate. From 1918 he was chief judge in equity. ${ }^{38} \mathrm{He}$ was also in 1918 royal commissioner in an inquiry into the 1916 convictions and sentences of 12 Industrial Workers of the World sympathisers.

Senior puisne judge when the chief justice, Sir William Cullen, resigned in 1925, Philip was appointed in his place, 'the first time since the appointment of Alfred Stephen [when] the government decided to promote the senior judge as Chief Justice'. ${ }^{39}$ Shortly after his appointment, the Sydney Sunday Times carried a profile of Belinda, describing her as bringing 'to the position of wife of the Chief Justice of New South Wales an immense store of knowledge of social problems, and an equal amount of charity'; she was a 'ceaselessly busy woman'. ${ }^{40}$

Sir Philip left office in 1933, 'after a term exceeded only by Sir Alfred Stephen'. ${ }^{41}$ He was lieutenant-governor from 1930, and several times administered the state. ${ }^{42}$ In his first year in the position, as adviser to the governor, Sir Philip Game, he had been 'drawn into the constitutional imbroglio that led to the dismissal of [premier J. T.] Lang. ${ }^{43}$ At his funeral in September 1938, Bishop Arnold Wylde described him as 'sound in judgment; wise in counsel; expert in knowledge; tolerant, and of wide sympathy; kindly and gracious, and with a deep love of everything beautiful in life. ${ }^{44}$

All three of Sir Philip's children —all sons—entered the law. His eldest son, Kenneth Whistler, received his LLB in 1914, and then, after World War I had broken out while he was on holiday in England, enlisted. He began legal practice, having been admitted to the New South Wales Bar in 1915, after his full-time military duties ended in late 1919. By this time, he was also a married man; he and Jessie Mary Grey Lillingston had been married in February 1916. Born in 1889 in India, Jessie had met Kenneth at the University of Sydney, where she gained a BA in 1911; the pair had both played hockey, and belonged to the university's dramatic society. ${ }^{45}$ Jessie, who as a child had prayed to be turned into a boy so as to escape the restrictions placed on girls, became a committed feminist advocate. ${ }^{46}$

\footnotetext{
38 Bennett, Portraits of the Chief Justices, 39-40.

39 'Chief Justice. Mr. Justice Street', Sydney Morning Herald, 21 January 1925, 14; Bennett, Portraits of the Chief Justices, 40.

40 'Wives of Our Famous Men. Mrs. P. W. Street', Sunday Times (Sydney), 22 February 1925, 13.

41 J. M. Bennett, 'Street, Sir Philip Whistler (1863-1938)', Australian Dictionary of Biography, National Centre of Biography, The Australian National University, adb.anu.edu.au/biography/street-sir-philip-whistler-8696/ text15217, published first in hardcopy 1990, accessed online 22 May 2014.

42 Bennett, Portraits of the Chief Justices, 41.

43 Bennett, 'Street, Sir Philip Whistler (1863-1938)'.

44 'State Funeral. Late Sir Philip Street. Impressive Scenes', Sydney Morning Herald, 14 September 1938, 18.

45 Lenore Coltheart, ed., Jessie Street: A Revised Autobiography (Sydney: The Federation Press, 2004), 21, 23.

46 Coltheart, Jessie Street, 8.
} 
From 1921 to 1927 Kenneth lectured in law, part time, at the University of Sydney; he also had a general practice. In 1927 he was appointed to the Industrial Commission, and in 1931 to the bench of the Supreme Court of New South Wales. ${ }^{47}$ His father being then chief justice, Kenneth became 'a "brother judge" of his father'. ${ }^{48}$ This unusual circumstance was remarked upon in the press. ${ }^{49}$ Acting chief justice and senior puisne judge when Sir Frederick Jordan died, he became chief justice in 1950. $\mathrm{He}$ 'was assured that the legal profession's regard for him was "based on its knowledge of him alone and not on any reflected glory of his ancestor". ${ }^{50}$ Sir Kenneth retired at the age of 70 in 1960. He had been lieutenant-governor since 1950, and remained in the role until he died in February 1972. Like his father, he administered the state several times. ${ }^{51}$

Meanwhile, Jessie became well known for her political views as a feminist activist, campaigner for Aboriginal rights and supporter of peace and socialism. President of the United Associations of Women for many years, by 1943 she was 'Australia's leading feminist'. ${ }^{52}$ She was a member of the Australian Labor Party, twice defeated for election in the seat of Wentworth, in 1943 and 1946, and in 1945 was the only female adviser in the Australian delegation to the United Nations Conference on International Organization' in San Francisco..$^{53}$ In 1949 she stood for election as an Independent Labour candidate in the seat of Phillip. In the context of widespread fear of the 'red menace', she was also by this time somewhat notorious. Her interest in and sympathy for socialism and the USSR had led to criticism, and she came to be called 'Red Jessie'. ${ }^{54}$ After spending some years overseas, she returned to Australia in 1960 and began work on her memoirs; she died in 1970.

Sir Philip's second son, Laurence Whistler, had just become an associate to his father when World War I broke out in 1914. He took part in the Gallipoli landings on 25 April 1915 and was killed in action in May. ${ }^{55}$ Another Street whose legal career was cut short by the war was Geoff, Philip's nephew. He had entered the University of Sydney intending to pursue a legal profession, but his undergraduate studies were interrupted by the outbreak of war. Returning from service in the Australian Imperial

\footnotetext{
47 Bennett, Portraits of the Chief Justices, 48.

48 Bennett, Portraits of the Chief Justices, 47.

49 For example: 'Father and Son. Judges at One Time', Advocate (Burnie, Tas.), 16 December 1927, 5.

50 J. M. Bennett, 'Street, Sir Kenneth Whistler (1890-1972)', Australian Dictionary of Biography, National Centre of Biography, The Australian National University, adb.anu.edu.au/biography/street-sir-kenneth-whistler-11790/ text21091, published first in hardcopy 2002, accessed online 22 May 2014.

51 Bennett, Portraits of the Chief Justices, 49.

52 Heather Radi, 'Street, Lady Jessie Mary (1889-1970)', Australian Dictionary of Biography, National Centre of Biography, The Australian National University, adb.anu.edu.au/biography/street-jessie-mary-grey-11789/ text21089, published first in hardcopy 2002, accessed online 12 June 2014.

53 Radi, 'Street, Lady Jessie Mary (1889-1970)'.

54 Coltheart, Jessie Street, 217; Geraldine O’Brien, Dynasties 2: More Remarkable and Influential Australian Families (Sydney: ABC Books, 2006), 211.

55 Street, Annals, 182-83.
} 
Force, he became a pastoralist and member of the federal House of Representatives. ${ }^{56}$ Minister of defence from November 1938, he was killed in 1940 in the Canberra air disaster, together with Jim Fairbairn, the minister for air; Sir Harry Gullett, the vicepresident of the executive council; and Sir Brudenell White, the chief of the general staff. ${ }^{57}$ Only two months before, along with Fairbairn, he had survived another crash with minor injuries. ${ }^{58}$

Ernest Whistler, the youngest of Sir Philip's children, was admitted to the Bar in 1924, having been an associate to his father while a student at law. Like his father, he preferred the equity jurisdiction, and he built up a significant practice in this area. His wife, Norah Knox, was a niece of Sir Adrian Knox, chief justice of the High Court of Australia. ${ }^{59}$ However, suffering ill health, he later left the law and entered business; he was a director of the Commercial Banking Co. of Sydney Ltd and of Tooheys Brewery Ltd, and chairman of City Mutual Fire Insurance Co. Ltd and Geigy (Australasia) Pty Ltd. ${ }^{60}$

A third-generation chief justice of New South Wales, and lieutenant-governor, was Laurence Whistler Street. Born to Kenneth and Jessie in 1926, he served in the Royal Australian Naval Reserve in World War II. Later in life, he recalled that 'it was more or less taken for granted that I would do law, ever since I was in primary school', and that he was keen to begin. ${ }^{61} \mathrm{He}$ graduated from the University of Sydney with a law degree in 1950, having as a student been associate to Sir William Owen, a Supreme Court judge. ${ }^{62}$ As a young lawyer, he later remembered, he was 'very anxious to succeed on my own right, rather than simply as a son of a prominent father'. ${ }^{63} \mathrm{He}$ was admitted to the Bar in 1951 and appointed QC in 1963; he also lectured in law at the University of Sydney for some years. Appointed as a Supreme Court judge in 1965, he became chief justice and lieutenant-governor in $1974 .{ }^{64}$ In the media, the unusual circumstance of three chief justices in one family was noted. 'Chief Justice Street?' asked the Woman's Day, 'Now That Sounds Familiar...' ${ }^{65}$ Sir Laurence retired in 1988 and became a commercial mediator.

\footnotetext{
56 Street, Annals, 128-29.

57 'Army Chiefs Perish in Canberra Air Disaster', Canberra Times, 14 August 1940, 1.

58 'Ministers in Air Crash. Escape with Minor Injuries', Canberra Times, 4 June 1940, 3.

59 Street, Annals, 185; 'Society Wedding', Sydney Morning Herald, 22 April 1925, 16.

60 O’Brien, Dynasties 2, 217; 'Death of Mr E. W. Street at 69', Sydney Morning Herald, 18 August 1967, 10.

61 O'Brien, Dynasties 2, 218.

62 Bennett, Portraits of the Chief Justices, 63.

63 Australian Broadcasting Commission, 'Street', Dynasties, Series 3, Episode 1, 9 November 2004, transcript, accessed 12 June 2014, www.abc.net.au/dynasties/txt/s1005646.htm.

64 Bennett, Portraits of the Chief Justices, 64.

65 Marianne Pretorius, 'Chief Justice Street? Now That Sounds Familiar...' Woman's Day, 3 June 1974, 4-5, 9. See also, for example: Gavin Souter, 'A Recessive Gene That Came Good', Sydney Morning Herald, 12 April 1974, 7; David Armstrong, 'A Third Chief Justice in the Family', Australian, 11 April 1974, 1.
} 
One of Sir Laurence's daughters, Sylvia Emmett, became a federal magistrate; another, Sarah, was admitted as a solicitor and became an employment recruiter; and a son, Alexander Whistler, also entered the law, being admitted to the Bar in 1982 and becoming an SC. ${ }^{66}$ In 2004 he told the Australian Broadcasting Corporation's Dynasties television program that he wore his father's wig and bar jacket, and that he had in his chambers books belonging to his father, grandfather and great-grandfather. 'I'm extremely aware of the heritage every time I put on my wig and gown and every time I walk into court,' he said. ${ }^{67}$ Other descendants have also continued the family's legal tradition.

These two families — the Stephens and the Streets—are not the only prominent legal families in Australia. There are also, for instance, the Windeyers, the a'Becketts and the Winnekes. Nor are these the only 'dynasties' in Australia, using the term in the sense of families in which a succession of members have made their mark in the same field. There are political dynasties, such as the Downers, Creans, Katters and Anthonys; business and philanthropic dynasties, like the Myers or the Horderns; media dynasties, including the Fairfaxes, the Symes, the Packers and the Murdochs; and even artistic dynasties, such as the Boyds. Many of their stories are also to be found in the Australian Dictionary of Biography and associated People Australia websites — or likely will be one day. As many reviewers of the $A D B$ have noted over its long life, it is the history of Australia writ through individual lives. In the stories of these dynastic families, it is also the histories of many varied professions, writ through the lives of the dynamic and engaging characters who contributed to those professions in Australia, and who flourished in them.

66 O’Brien, Dynasties 2, 221; Australian Broadcasting Commission, 'Alexander Whistler Street', Dynasties, Series 3, Episode 1, family tree, 9 November 2004, accessed 12 June 2014, www.abc.net.au/dynasties/txt/s1228318.htm; Susan Wyndham, 'Sir Laurence Street: The Man Who Can Challenge a Government', Good Weekend, 16 February 1985, 7. 67 Australian Broadcasting Commission, 'Street', Dynasties, Series 3, Episode 1, 9 November 2004, transcript, accessed 12 June 2014, www.abc.net.au/dynasties/txt/s1005646.htm. 
This text is taken from Australian Journal of Biography and History: No. 1, 2018, published 2018 by ANU Press, The Australian National University, Canberra, Australia.

doi.org/10.22459/AJBH.2018.07 